\title{
EXUDATE PH AND FLOODING TESTS TO EVALUATE THE PHYSIOLOGICAL QUALITY OF SOYBEAN SEEDS ${ }^{1}$
}

\author{
JOSIANE VOGEL CORTINA THEODORO ${ }^{2}$, FERNANDA BRITO CARDOSO ${ }^{2}$, CARLOS HENRIQUE QUEIROZ \\ REGO $^{2}$, ANA CARINA DA SILVA CÂNDIDO ${ }^{2}$, CHARLINE ZARATIN ALVES $^{2 *}$
}

\begin{abstract}
The present study aimed to assess the variations in the parameters of the exudate $\mathrm{pH}$ and flooding tests to evaluate the physiological quality of soybean seeds. We subjected the lots of soybean seeds to germination, emergence, exudate $\mathrm{pH}$, and flooding tests. Further, water content of the seeds, first count of germination, and emergence speed index were also determined. The exudate $\mathrm{pH}$ test studied the variations in the soaking period and temperature, while the flooding test assessed the variations in the amount of water and temperature at different periods of immersion. The experiment design was completely randomized. The results were presented as means and were compared using the Scott-Knott test at 5\% probability. The Pearson's correlation coefficient between the exudate $\mathrm{pH}$ and emergence of seedlings, and also between the flooding test result and emergence of seedlings were calculated. The results of the study indicated that the exudate $\mathrm{pH}$ test can be used to evaluate the physiological quality of soybean seeds after $30 \mathrm{~min}$ of imbibition at $20{ }^{\circ} \mathrm{C}$. Further, the flooding test was efficient in evaluating the vigor of soybean seeds after $4 \mathrm{~h}$ of immersion either in $50 \mathrm{~mL}$ of distilled water at $25{ }^{\circ} \mathrm{C}$ or in $75 \mathrm{~mL}$ of distilled water at $30{ }^{\circ} \mathrm{C}$.
\end{abstract}

Keywords: Glycine max. Viability. Vigor.

\section{TESTE DO pH DO EXSUDATO E ALAGAMENTO PARA AVALIAR A QUALIDADE FISIOLÓGICA DE SEMENTES DE SOJA}

RESUMO - O trabalho teve como objetivo estudar variações nos parâmetros envolvidos no teste do pH do exsudato e alagamento para caracterização da qualidade físiológica de sementes de soja. Inicialmente, foi determinado o teor de água e realizados os testes de germinação, primeira contagem, emergência e índice de velocidade de emergência. No teste do $\mathrm{pH}$ do exsudato foram estudadas variações no período de embebição e temperatura; e no teste de alagamento foram estudadas variações na quantidade de água e temperatura. $\mathrm{O}$ experimento foi realizado em delineamento inteiramente casualizado com quatro repetições, e as médias comparadas pelo teste de Scott-Knott a 5\% de probabilidade. Foi estimado o coeficiente de correlação de Pearson entre os testes do $\mathrm{pH}$ do exsudato e alagamento com a emergência de plântulas. $\mathrm{O}$ teste do $\mathrm{pH}$ do exsudato pode ser utilizado na avaliação do potencial fisiológico de sementes de soja, sendo que este deve ser realizado na temperatura de $20^{\circ} \mathrm{C}$ por 30 minutos de embebição. $\mathrm{O}$ teste de alagamento é eficiente na avaliação do vigor de sementes de soja, podendo ser realizado nas combinações $25^{\circ} \mathrm{C} / 50 \mathrm{~mL}$ ou $30{ }^{\circ} \mathrm{C} / 75 \mathrm{~mL}$, durante $4 \mathrm{~h}$.

Palavras-chave: Glycine max. Viabilidade. Vigor.

\footnotetext{
${ }^{*}$ Corresponding author

${ }^{1}$ Received for publication in 06/20/2017; accepted in 09/14/2017.

Paper extracted from the master's dissertation of the first author.

${ }^{2}$ Department of Agronomy, Universidade Federal de Mato Grosso do Sul, Chapadão do Sul, MS, Brazil; josiane.theodoro@ufms.br ORCID: 0000-0001-5876-3682, fernandabcardoso@hotmail.com - ORCID: 0000-0002-0370-261X, carlosqueirozagro@gmail.com ORCID: 0000-0001-5483-9264, ana.candido@ufms.br - ORCID: 0000-0002-9230-4807, charline.alves@ufms.br - ORCID: 0000-00016228-078X
} 


\section{INTRODUCTION}

The speed at which trustworthy results are obtained is one of the important factors considered while evaluating seed quality. It allows agility in decision making, enables its use on a broader scale, reduces the risks and costs involved in operations, such as harvesting, processing, storage, and marketing (REIS et al., 2010; BARBIERI et al., 2012; HILST et al., 2012). Therefore, rapid tests are essential for the evaluation of viability of soybean (Glycine max) seeds as the physiological qualities of the seeds are expressed with greater precision within a certain period.

Despite the differences in their techniques, vigor tests, in general, are intended to detect significant variations in the physiological qualities of marketable lots of seeds. These tests help in classifying seeds based on levels of vigor, especially in the proportion of seedling emergence in the field (MARCOS-FILHO, 2015).

The evaluation of viability of seeds by exudate $\mathrm{pH}$ test is inexpensive as well as promising when compared with that of the tetrazolium test. The exudate $\mathrm{pH}$ test can be applied easily, and the results obtained are at a faster rate. It avoids the use and/or unnecessary storage of seed lots with lower vigor (RAMOS et al., 2012). However, some researchers have highlighted the importance of developing and/or modifying these rapid vigor tests for different species, since the evaluation of seed quality depends on the efficiency of the procedures involved (LOPES; SILVA; VIEIRA, 2013).

Flooding of seeds is a simple, yet promising test (CUSTÓDIO et al., 2002) to identify seed lots that can withstand injury by rapid imbibition. When seeds are soaked in water, oxygen available to them is greatly reduced, and a large quantity of water quickly enters the seed, thus, injuring the seed by imbibition. The seed with injury has less energy for germination, resulting in lower vigor of the seed.

There is limited information available on vigor tests. There is also a need for standardization of such tests to evaluate the quality of seed lots in a simpler way. In this milieu, the present study was conducted to assess the variations in the parameters of the exudate $\mathrm{pH}$ and flooding tests and the combinations of these parameters to differentiate lots of soybean seeds with different levels of vigor.

\section{MATERIAL AND METHODS}

The experiment was carried out at the Laboratory of Seed Technology, Federal University of Mato Grosso do Sul (UFMS), Campus of Chapadão do Sul/MS with nine commercial lots of soybean seeds, cultivar Anta 82. The initial evaluation of quality of the seed lots involved the following: determining the water content of the seeds; subjecting the seeds to germination and emergence tests; determining the first count of germination and emergence speed index.

Water content of the seeds was determined after drying the seeds at $105 \pm 3{ }^{\circ} \mathrm{C}$ for $24 \mathrm{~h}$ according to the Rules for Seeds Testing (BRASIL, 2009).

Germination test was carried out in eight replicates with 50 seeds each. The seeds were distributed on germitest papers previously moistened with distilled water, equivalent to 2.5 times the weight of the non-hydrated paper (BRASIL, 2009), in a germinator at $25{ }^{\circ} \mathrm{C}$. Evaluations were carried out on the fifth and eighth day after sowing. First count of germination was carried out in conjunction with the germination test by counting the number of normal seedlings obtained five days after sowing.

Emergence test was carried out in four replicates with 50 seeds each. The seeds were sown in expanded polystyrene trays with commercial substrate, then placed in a greenhouse and irrigated twice a day. Seeds were evaluated ten days after sowing. Emergence speed index (ESI) was calculated in conjunction with the emergence of seedlings according to the formula proposed by Maguire (1962).

For the exudate $\mathrm{pH}$ test, the following two solutions were prepared: (1) $1 \mathrm{~g}$ of phenolphthalein dissolved in $100 \mathrm{~mL}$ of absolute alcohol, and then added to $100 \mathrm{~mL}$ of distilled, boiled water (AMARAL; PESKE, 1984) (2) $0.8 \mathrm{~g}$ of sodium carbonate in $1000 \mathrm{~mL}$ of distilled water and then boiled (CABRERA; PESKE, 2002). Exudate $\mathrm{pH}$ test was carried out in four replicates with 25 seeds each. The seeds were individually immersed in plastic cells with $5 \mathrm{~mL}$ of distilled water for 20,30 , and $40 \mathrm{~min}$ at 20,25 , and $30{ }^{\circ} \mathrm{C}$. After each treatment period, three drops each of phenolphthalein and sodium carbonate solutions were added to the seeds, and then homogenized using a glass rod. The reading was taken immediately upon the contact of the indicator solution with the imbibition solution. The interpretation was based on the coloring of the solution: pink solution indicated viable seeds and colorless solution indicated nonviable seeds.

Four replicates of 50 seeds per treatment were used for the flooding test. Seeds were immersed in distilled water in $200 \mathrm{~mL}$ plastic cups, which were then kept in a germinator at 25 and $30{ }^{\circ} \mathrm{C}$ in the darkness, and later subjected to germination test (BRASIL, 2009). For the flooding test, variations in the immersion period $(4,8,12,16,20$, and $24 \mathrm{~h})$ and amount of water ( 50 and $75 \mathrm{~mL}$ ) were evaluated. The water content of the seeds before and after each flooding period and the percentage of normal seedlings that germinated after each treatment were determined.

The experiment design was completely randomized with four replicates. The results were 
subjected to analysis of variance and compared using the Scott-Knott test at 5\% probability. The Pearson's correlation coefficient was calculated between the exudate $\mathrm{pH}$ and emergence of seedlings, and also between the flooding test result and emergence of seedlings.

\section{RESULTS AND DISCUSSION}

The initial water content of soybean seed lots was not analyzed statistically (Table 1 ). No variation greater than $2 \%$ in the water content between lots was observed in the present study. In tests, such as exudate $\mathrm{pH}$ and flooding tests, that expose seeds to hydration, seed samples with sharp variation in the water content are not recommended since dried seeds are subject to further deterioration during the tests. The reason for this deterioration might be the contact water allowing quick imbibition and restarting the metabolism of the seeds in a defective way or causing the cell membranes of the seeds to rupture, thus interfering with the interpretation of the results (MARCOS-FILHO, 2015).

Table 1. Water content (WC), germination (G), first count of germination (FCG), emergence (E), and emergence speed index (ESI) of the nine lots of soybean seeds.

\begin{tabular}{|c|c|c|c|c|c|}
\hline Lots & $=\frac{\mathrm{WC}}{\%}$ & $-\frac{\mathrm{G}}{\%}$ & $\underset{\%}{\mathrm{FCG}}$ & $\frac{E}{\%}$ & ESI \\
\hline 1 & 8.7 & $92 \mathrm{a}$ & $92 \mathrm{a}$ & $86 a$ & $2.75 \mathrm{a}$ \\
\hline 2 & 8.6 & $95 \mathrm{a}$ & $95 \mathrm{a}$ & $66 \mathrm{~b}$ & $2.00 \mathrm{a}$ \\
\hline 3 & 8.7 & $92 \mathrm{a}$ & $91 \mathrm{a}$ & $50 \mathrm{c}$ & $1.50 \mathrm{~b}$ \\
\hline 4 & 8.9 & $92 \mathrm{a}$ & $91 \mathrm{a}$ & $71 \mathrm{~b}$ & $2.25 \mathrm{a}$ \\
\hline 5 & 8.6 & $93 \mathrm{a}$ & $90 \mathrm{a}$ & $86 \mathrm{a}$ & $3.00 \mathrm{a}$ \\
\hline 6 & 8.5 & $94 \mathrm{a}$ & $47 \mathrm{~b}$ & $73 \mathrm{~b}$ & $2.00 \mathrm{a}$ \\
\hline 7 & 8.4 & $95 \mathrm{a}$ & $47 \mathrm{~b}$ & $65 \mathrm{~b}$ & $1.75 \mathrm{~b}$ \\
\hline 8 & 7.7 & $92 \mathrm{a}$ & $45 \mathrm{~b}$ & $77 \mathrm{a}$ & $2.25 \mathrm{a}$ \\
\hline 9 & 8.5 & $95 \mathrm{a}$ & $48 \mathrm{~b}$ & $29 \mathrm{~d}$ & $0.75 \mathrm{c}$ \\
\hline
\end{tabular}

In the columns, means followed by different letters differ by the Scott-Knott test $(\mathrm{P}<0.05)$.

No statistical difference in germination between lots was observed in the present study. However, the first count of germination made it possible to separate the seed lots into two distinct groups based on the levels of vigor - lots 1, 2, 3, 4, and 5 had higher means than that of the other lots. For seed vigor tests, the seed lots used should have similar germination potential. They should also be accepted commercially, since the main objective of these tests is to complement the results of germination test and identify quality differences among lots with similar germination potential (MARCOS-FILHO, 2015).

In the seedlings emergence test, seeds are exposed to adverse climatic and soil conditions (LARRÉ; ZEPKA; MORAES, 2007). This allows segregation of seed lots with different levels of vigor (OLIVEIRA et al., 2009). In the present study, seeds lots were separated into four groups based on their levels of vigor: lots 1,5 , and 8 were found to be more vigorous, while lot 9 was found to be least vigorous. Further, the emergence speed indices revealed lots $1,2,4,5,6$, and 7 to be more vigorous and lot 9 to be least vigorous (Table 1).

There was no significant difference in germination between lots in the present study. However, there was significant difference in seedling emergence between lots. This was probably due to the conditions under which the tests were carried out.
The germination test was performed under controlled temperature and humidity, while the emergence test was carried out under field conditions.

For vigor tests to be considered efficient, the results of such tests should reflect the proportion of seedling emergence in the field. The tests should estimate the behavior of seed lots after sowing them in a broad range of environmental conditions (ILBI; KAVAK; ESER, 2009).

\section{Test of exudate pH}

Table 2 shows the Pearson's correlation coefficients (r) between the seedling emergence and exudate $\mathrm{pH}$. A significant correlation $(0.786)$ was observed after $30 \mathrm{~min}$ of imbibition at $20{ }^{\circ} \mathrm{C}$. The exudate $\mathrm{pH}$ test also ranked the soybean seed lots similar to that of the seedling emergence test.

In corn seeds, Cabrera and Peske (2002) observed that seed viability estimated by the individual exudate $\mathrm{pH}$ test is better achieved after an imbibition period of $20 \mathrm{~min}$ at 20 to $25^{\circ} \mathrm{C}$. A study on rapid evaluation of the physiological quality of pea seeds with soaking periods of $15,30,45$, and $60 \mathrm{~min}$ at room temperature $\left(20{ }^{\circ} \mathrm{C}-25{ }^{\circ} \mathrm{C}\right)$ was conducted by Rech, Villela and Tillmann (1999). Their study concluded that the individual exudate $\mathrm{pH}$ test results after $30 \mathrm{~min}$ of imbibition allows quick estimation of viability of pea seeds. 
Table 2. Correlation coefficient (r) between the seedling emergence and exudate $\mathrm{pH}$ at 20,25 , and $30{ }^{\circ} \mathrm{C}$ and imbibition periods of 20, 30, and 40 min of the nine lots of soybean seeds.

\begin{tabular}{lccr}
\hline Temperature $\left({ }^{\circ} \mathrm{C}\right)$ & & Imbibition period & \\
\hline & $20^{\prime}$ & $30^{\prime}$ & $40^{\prime}$ \\
\hline 20 & $-0.136^{\text {ns }}$ & $0.786^{*}$ & $0.177^{\text {ns }}$ \\
25 & $-0.147^{\text {ns }}$ & $-0.113^{\text {ns }}$ & $0.412^{\text {ns }}$ \\
30 & $-0.182^{\text {ns }}$ & $0.141^{\text {ns }}$ & $-0.086^{\text {ns }}$ \\
\hline
\end{tabular}

*Significant at $5 \%$ probability; ${ }^{\mathrm{ns}}$ not significant.

The results of the present study are similar to that of the study conducted by Amaral and Peske (1984). They distinguished viable from nonviable soybean seeds after a $30 \mathrm{~min}$ imbibition period at $25{ }^{\circ} \mathrm{C}$ using the exudate $\mathrm{pH}$ test with the use of a drop each of sodium carbonate and phenolphthalein solutions in $2 \mathrm{~mL}$ of exudate of each seed.

Santos et al. (2011) tested soybean seeds soaked in $2 \mathrm{~mL}$ of distilled water for $30 \mathrm{~min}$ at $25{ }^{\circ} \mathrm{C}$, and then placed one drop each of phenolphthalein and sodium carbonate solutions. The results revealed that the exudate $\mathrm{pH}$ test was not efficient in the segregation of seed lots based on their physiological quality. However, this outcome was unlike the observations made in the present study. This variation might be due to the use of $5 \mathrm{~mL}$ of distilled water and also the use of three drops each of phenolphthalein and sodium carbonate solutions after the imbibition period in the present study.

The exudate $\mathrm{pH}$ test was efficient in quickly estimating the viability of Araucaria angustifolia seeds when performed on embryos excised and soaked in distilled water for $30 \mathrm{~min}$ (ARALDI; COELHO, 2015). In contrast, Barboza et al. (2014) found no effect of soaking period $(20,40,60$, and $80 \mathrm{~min}$ ) on the exudate $\mathrm{pH}$ test results in Guazuma ulmifolia seeds. It should be noted that assessing individual seeds is important considering that there are variations in the quality of seeds within a lot. This might be due to the inability of all the seeds in a lot to reach physiological maturity at the same time, and therefore, do not attain the highest quality simultaneously, which is reflected in the post-harvest viability. Thus, further studies on exudate $\mathrm{pH}$ test are recommended in order to observe variations in the results in soybean seeds with different amounts of water, besides the variation caused by the number of drops of phenolphthalein and sodium carbonate solutions.

\section{Flooding test}

The water content of soybean seeds after the flooding test is shown in Table 3. Lot 9 had the lowest water content both at 25 and $30{ }^{\circ} \mathrm{C}$ after $4 \mathrm{~h}$ of immersion. Even after $24 \mathrm{~h}$ of immersion in distilled water, the seeds of lot 9 continued to have the lowest water content.

According to Bewley and Black (1994), water uptake by a seed is triphasic. Phase I of water uptake is purely physical, and it depends only on the bond of water to the matrix of the seed. Both live and dead seeds exhibit similar behavior. Phase II is characterized by complete hydration of the seed, which is stabilized by the balance between the osmotic potential and potential pressure. During this phase, the seed absorbs water slowly, and the embryo cannot grow further due to the resumption of growth of the embryonic axis. In phase III, there is increase in the uptake of water, and radicle protrusion is also observed. In the present study, rapid absorption of water by all the nine lots of soybean seeds was observed until $4 \mathrm{~h}$ after the immersion of seeds in distilled water. After this period there was stabilization, which was possibly related to phase I of water uptake that probably lasted for a little less than $4 \mathrm{~h}$ in soybean seeds.

Table 4 shows the correlation between the flooding test result and seedling emergence. Of the various combinations assessed in the present study, seeds immersed in $50 \mathrm{~mL}$ of distilled water at $25^{\circ} \mathrm{C}$ for $4 \mathrm{~h}, 75 \mathrm{~mL}$ of distilled water at $30^{\circ} \mathrm{C}$ for $4 \mathrm{~h}$, and $50 \mathrm{~mL}$ of distilled water at $30{ }^{\circ} \mathrm{C}$ for $12 \mathrm{~h}$ exhibited significant correlation with the seedling emergence. During the flooding period, the availability of oxygen is reduced and a large quantity of water quickly enters the seed due to the difference in the water potential between the seed interior and the environment. This induces fermentative metabolism and injures the seed by imbibition (COSTA et al., 2008a; COSTA et al., 2008b). The seed with some kind of injury has less energy for germination; such seeds will be negatively affected by the flooding process water, thus lowering the vigor (CUSTÓDIO et al., 2009). 
J. V. C. THEODORO et al

Table 3. Water content (\%) of soybean seeds at different periods of immersion.

\begin{tabular}{|c|c|c|c|c|c|c|}
\hline & \multicolumn{6}{|c|}{$25^{\circ} \mathrm{C}, 50 \mathrm{~mL}$ distilled water } \\
\hline Lots & $4 \mathrm{~h}$ & $8 \mathrm{~h}$ & $12 \mathrm{~h}$ & $16 \mathrm{~h}$ & $20 \mathrm{~h}$ & $24 \mathrm{~h}$ \\
\hline 1 & 53.7 & 58.9 & 62.3 & 60.5 & 60.6 & 61.0 \\
\hline 2 & 53.6 & 58.9 & 59.8 & 60.4 & 60.5 & 60.6 \\
\hline 3 & 54.0 & 59.5 & 61.1 & 61.5 & 61.4 & 62.4 \\
\hline 4 & 53.3 & 60.9 & 59.9 & 60.5 & 60.9 & 60.9 \\
\hline 5 & 55.1 & 61.1 & 61.9 & 62.7 & 63.1 & 63.1 \\
\hline 6 & 55.5 & 58.8 & 59.8 & 60.0 & 57.9 & 60.9 \\
\hline 7 & 55.2 & 61.4 & 62.0 & 62.6 & 64.6 & 63.8 \\
\hline 8 & 55.2 & 61.1 & 62.2 & 62.6 & 63.0 & 62.9 \\
\hline \multirow[t]{2}{*}{9} & 51.7 & 57.3 & 58.9 & 59.2 & 59.9 & 60.3 \\
\hline & \multicolumn{6}{|c|}{$25^{\circ} \mathrm{C}, 75 \mathrm{~mL}$ distilled water } \\
\hline 1 & 54.1 & 58.9 & 59.4 & 60.1 & 60.1 & 60.2 \\
\hline 2 & 54.0 & 59.4 & 59.7 & 60.6 & 60.6 & 60.6 \\
\hline 3 & 53.9 & 61.5 & 59.7 & 61.3 & 61.1 & 57.8 \\
\hline 4 & 53.5 & 59.2 & 59.3 & 61.2 & 60.4 & 60.6 \\
\hline 5 & 56.7 & 61.9 & 61.9 & 62.6 & 63.3 & 63.7 \\
\hline 6 & 54.4 & 58.8 & 60.6 & 60.2 & 60.8 & 60.5 \\
\hline 7 & 56.9 & 61.3 & 62.1 & 62.7 & 63.6 & 62.1 \\
\hline 8 & 55.1 & 55.3 & 61.4 & 61.5 & 62.4 & 63.1 \\
\hline \multirow[t]{2}{*}{9} & 51.7 & 58.2 & 57.9 & 59.3 & 58.8 & 59.3 \\
\hline & \multicolumn{6}{|c|}{$30{ }^{\circ} \mathrm{C}, 50 \mathrm{~mL}$ distilled water } \\
\hline 1 & 57.0 & 59.5 & 60.3 & 60.7 & 61.5 & 60.3 \\
\hline 2 & 56.6 & 59.3 & 60.3 & 61.1 & 60.2 & 60.9 \\
\hline 3 & 56.6 & 59.7 & 61.2 & 61.8 & 61.2 & 61.4 \\
\hline 4 & 56.6 & 59.4 & 60.9 & 61.7 & 61.8 & 60.7 \\
\hline 5 & 59.2 & 61.3 & 62.6 & 63.6 & 64.3 & 63.0 \\
\hline 6 & 56.3 & 59.8 & 61.3 & 62.2 & 61.4 & 60.9 \\
\hline 7 & 58.2 & 62.1 & 62.6 & 63.9 & 63.7 & 57.2 \\
\hline 8 & 59.1 & 61.8 & 62.8 & 63.3 & 63.9 & 63.5 \\
\hline \multirow[t]{2}{*}{9} & 54.5 & 57.7 & 58.8 & 59.9 & 60.3 & 59.9 \\
\hline & \multicolumn{6}{|c|}{$30{ }^{\circ} \mathrm{C}, 75 \mathrm{~mL}$ distilled water } \\
\hline 1 & 56.7 & 59.0 & 60.2 & 60.2 & 60.5 & 60.3 \\
\hline 2 & 56.9 & 59.1 & 60.3 & 60.8 & 60.5 & 60.7 \\
\hline 3 & 57.0 & 60.1 & 61.4 & 62.0 & 61.4 & 61.0 \\
\hline 4 & 56.5 & 58.8 & 60.5 & 61.1 & 61.4 & 61.1 \\
\hline 5 & 59.6 & 61.2 & 62.7 & 62.8 & 63.4 & 62.4 \\
\hline 6 & 56.5 & 59.2 & 61.1 & 61.1 & 61.2 & 60.3 \\
\hline 7 & 58.7 & 61.2 & 63.3 & 63.5 & 63.7 & 62.9 \\
\hline 8 & 58.2 & 60.7 & 62.4 & 63.9 & 63.7 & 63.5 \\
\hline 9 & 54.4 & 58.1 & 59.3 & 60.3 & 60.3 & 59.9 \\
\hline
\end{tabular}

Table 4. Correlation coefficient (r) between the seedling emergence and flooding test result at 25 and $30{ }^{\circ} \mathrm{C}$ during different periods of flooding $(4,8,12,16,20$, and $24 \mathrm{~h})$ with 50 and $75 \mathrm{~mL}$ of distilled water in the nine lots of soybean seeds.

\begin{tabular}{|c|c|c|c|c|c|c|c|}
\hline \multirow{2}{*}{$\begin{array}{c}\text { Temperature } \\
\left({ }^{\circ} \mathrm{C}\right)\end{array}$} & \multirow{2}{*}{$\begin{array}{l}\text { Amount of } \\
\text { water }(\mathrm{mL})\end{array}$} & \multicolumn{6}{|c|}{ Flooding period (h) } \\
\hline & & & 8 & 12 & 16 & 20 & 24 \\
\hline $\begin{array}{r}25 \\
--5\end{array}$ & $\begin{array}{r}50 \\
-75 \\
-\quad-50 \\
75\end{array}$ & $\begin{array}{l}0.7723^{*} \\
0.4953^{\mathrm{ns}} \\
0.6280^{\mathrm{ns}} \\
0.8133^{*}\end{array}$ & $\begin{array}{l}0.2712^{\mathrm{ns}} \\
0.6383^{\mathrm{ns}} \\
0.347 \overline{1}^{\mathrm{ns}} \\
0.3318^{\mathrm{ns}}\end{array}$ & $\begin{array}{c}0.1470^{\mathrm{ns}} \\
0.4055^{\mathrm{ns}} \\
0.7617^{*} \\
0.3003^{\mathrm{ns}}\end{array}$ & $\begin{array}{l}0.2447^{\mathrm{ns}} \\
0.2540^{\mathrm{ns}} \\
0.3624^{\mathrm{ns}} \\
0.4309^{\mathrm{ns}}\end{array}$ & $\begin{array}{c}0.2325^{\mathrm{ns}} \\
0.0008^{\mathrm{ns}} \\
-0.2208^{\mathrm{ns}} \\
0.1491^{\mathrm{ns}}\end{array}$ & $\begin{array}{r}0.2258^{\mathrm{ns}} \\
0.6671^{*} \\
0.4339^{\mathrm{ns}} \\
-0.0738^{\mathrm{ns}}\end{array}$ \\
\hline
\end{tabular}

*Significant at $5 \%$ probability; ${ }^{\text {ns }}$ not significant.

The effects of flooding and temperature on seed germination have been observed by Wuebker, Mullen and Koehler (2001). Their study concluded that the seeds are susceptible to loss in their germination capacity when subjected to flooding for 1-48 h. During flooding, the seeds are injured due to rapid imbibition, i.e., large amount of water quickly enter the seeds in response to the difference in water potential between the seed interior and the environment inducing fermentative metabolism instead of aerobic metabolism (CRAWFORD, 1978).

Custódio et al. (2002) evaluated the effects of flooding in bean seeds at $25^{\circ} \mathrm{C}$ for $0,8,16,24,32$, 40 , and $48 \mathrm{~h}$. The results indicated a decrease in 
germination of the seed lots by $55 \%$ after $8 \mathrm{~h}$ of flooding. This confirms that when flooding test is employed in a laboratory, it can be a good indicator to differentiate bean seeds based on their physiological quality. Grzybowski, Vieira and Panobianco (2015) also noted the relevance of flooding test in the characterization of maize seed quality at $25^{\circ} \mathrm{C}$ for $48 \mathrm{~h}$.

The study on effect of flooding on seed germination and the establishment of crops under field conditions have indicated that the flooding test can be considered as a quick and an inexpensive selection test, presenting correlation with the emergence of plants in the field. This test can be used in the differentiation of seeds based on their physiological quality (BORGES et al., 2007).

The results of the present study revealed that the flooding the soybean seeds for $4 \mathrm{~h}$ either with $50 \mathrm{~mL}$ of distilled water at $25{ }^{\circ} \mathrm{C}$ or $75 \mathrm{~mL}$ of distilled water at $30^{\circ} \mathrm{C}$ to be effective in determining the vigor of soybean seeds. Ranking of lots of soybean seeds based on the levels of vigor by this method is similar to that of the emergence test. Furthermore, the test was also effective in identifying the levels of vigor between seeds with similar as well as higher seed germination (above $92 \%)$.

\section{CONCLUSIONS}

Exudate $\mathrm{pH}$ test can be used to evaluate the physiological quality of soybean seeds after $30 \mathrm{~min}$ of imbibition at $20^{\circ} \mathrm{C}$.

The flooding test was efficient in evaluating the soybean seed vigor when the seeds were immersed for $4 \mathrm{~h}$ either in $50 \mathrm{~mL}$ of distilled water at $25^{\circ} \mathrm{C}$ or in $75 \mathrm{~mL}$ of distilled water at $30^{\circ} \mathrm{C}$.

\section{REFERENCES}

AMARAL, A. S.; PESKE, S. T. pH do exsudato para estimar, em 30 minutos, a viabilidade de sementes de soja. Revista Brasileira de Sementes, Londrina, v. 6, n. 3, p. 85-92, 1984.

ARALDI, C. G.; COELHO, C. M. M. pH do exsudato na avaliação da viabilidade de sementes de Araucaria angustifolia. Floresta e Ambiente, Rio de Janeiro, v. 22, n. 3, p. 426-433, 2015.

BARBIERI, A. P. P. et al. Teste de lixiviação de potássio para a avaliação do vigor de sementes de arroz. Revista Brasileira de Sementes, Londrina, v. 34, n. 1, p. 117-124, 2012.

BARBOZA, V. R. S. et al. Potencial fisiológico de sementes de Guazuma ulmifolia Lam. através do teste do $\mathrm{pH}$ do exsudato. Enciclopédia Biosfera, Goiânia, v. 10, n. 18, p. 2327-2335, 2014.

BEWLEY, J. D.; BLACK, M. Seeds: physiology of development and germination. 2. ed. New York, Plenum Press. 1994. 445 p.

BORGES, K. C. F. et al. Germinação de sementes e emergência de plântulas de Licehea divaricata Mart. Revista Brasileira de Biociências, Porto Alegre, v. 5, Sup., p. 1008-1010, 2007.

BRASIL. Ministério da Agricultura, Pecuária e Abastecimento. Regras para análise de sementes. Secretaria de Defesa Agropecuária. Brasília: MAPA/ ACS, 2009. 395 p.

CABRERA, A. C.; PESKE, S. T. Testes do pH do exsudato para sementes de milho. Revista Brasileira de Sementes, Londrina, v. 24, n. 1, p. 134-140, 2002 .

COSTA, C. J. et al. Expressão de isoenzimas após a pré- hidratação de sementes de ervilha. Revista Brasileira de Sementes, Londrina, v. 30, n. 3, p. 130 $-138,2008 \mathrm{a}$.

COSTA, C. J. et al. Pré-hidratação de sementes de ervilha e sua interferência na avaliação do potencial fisiológico. Revista Brasileira de Sementes, Londrina, v. 30, n. 1, p. 198-207, 2008b.

CRAWFORD, R. M. M. Tolerance of anoxia and ethanol. In: HOOK, D. D.; CRAWFORD, R. M. M. (Eds.). Plant life in anaerobic environments. Cambridge: Ann Arbor Science, 1978. v. 1, cap. 5, p. 119-136.

CUSTÓDIO, C. C. et al. Efeito da submersão em água de sementes de feijão na germinação e no vigor. Revista Brasileira de Sementes, Londrina, v. 24, n. 2, p. 49-54, 2002.

CUSTÓDIO, C. C. et al. Water submersion of bean seeds in the vigour evaluation. Revista Brasileira de Ciências Agrárias, Recife, v. 4, n. 3, p. 261-266, 2009.

GRZYBOWSKI， C. R. S.; VIEIRA， R. D.; PANOBIANCO, M. Testes de estresse na avaliação do vigor de sementes de milho. Revista Ciência Agronômica, Fortaleza, v. 46, n. 3, p. 590-596, 2015 .

HILST, P. C. et al. Test of exudates color hues for evaluating the physiological potential of coffee (Coffea arabica L.) seeds. Revista Brasileira de Sementes, Londrina, v. 34, n. 2, p. 212-217, 2012.

ILBI, H.; KAVAK, S.; ESER, B. Cool germination 
test can be an alternative vigour test for maize. Seed Science and Technology, Cambridge, v. 37, n. 2, p. 516-519, 2009.

LARRÉ, C. F.; ZEPKA, A. P. S.; MORAES, D. M. Testes de germinação e emergência em sementes de maracujá submetidas a envelhecimento acelerado. Revista Brasileira de Biociências, Porto Alegre, v. 5, n. 2, p. 708-710, 2007.

LOPES, M. M.; SILVA, C. B.; VIEIRA, R. D. Physiological potential of eggplant seeds. Journal of Seed Science, Londrina, v. 35, n. 2, p. 225-230, 2013.

MAGUIRE, J. D. Speed of germination-aid in selection and evaluation for seedling emergence and vigor. Crop Science, Madison, v. 2, n. 1, p. 176-177, 1962.

MARCOS-FILHO, J. Fisiologia de sementes de plantas cultivadas. 2. ed. Londrina, PR: ABRATES, 2015. $660 \mathrm{p}$.

OLIVEIRA, A. C. S. et al. Testes de vigor em sementes baseados no desempenho de plântulas. Inter Science Place, Rio de Janeiro, v. 2, n. 4, p. 121, 2009.

RAMOS, K. M. O. et al. Electrical conductivity testing as applied to the assessment of freshly collected Kielmeyera coriacea Mart. seeds. ISRN Agronomy, Cairo, v. 2012, Article ID 378139, p. 1$5,2012$.

RECH, E. G.; VILLELA, F. A.; TILLMANN, M. A. A. Avaliação rápida da qualidade fisiológica de sementes de ervilha. Revista Brasileira de Sementes, Londrina, v. 21, n. 2, p. 1-9, 1999.

REIS, L. S. et al. LERCAFÉ: novo teste para estimar o potencial germinativo de sementes de cafeeiro (Coffea arabica L.). Revista Brasileira de Sementes, Londrina, v. 32, n. 1, p. 9-16, 2010.

SANTOS, J. F. et al. Avaliação do potencial fisiológico de lotes de sementes de soja. Revista Brasileira de Sementes, Londrina, v. 33, n. 4, p. 743 $-751,2011$.

WUEBKER, E. F.; MULLEN, R. E.; KOEHLER, K. Flooding and temperature effects on soybean germination. Crop Science, Madison, v. 41, n. 1, p. 1857-1861, 2001. 